\title{
The Implementation of the Flipped Classroom for Early Grade Students in Elementary School
}

\section{Lejar Retno Hidayah ${ }^{1^{*}}$, Ali Mustadi ${ }^{2}$}

1,2 Universitas Negeri Yogyakarta, Yogyakarta, Indonesia

\section{A R T I C L E I N F O}

Article history:

02 January 2021

Received in revised form

08 January 2021

Accepted 20 January

2021

Available online 25

February 2021

\section{Kata Kunci: \\ Flipped Classroom \\ Matematika \\ Keywords: \\ Flipped Classroom,}

Mathematics

\begin{abstract}
A B S T R A K
Paradigma pendidikan di era pandemi coronavirus abad 21 ini membutuhkan kajian penelitian yang lebih mendalam. Penelitian ini bertujuan untuk meningkatkan hasil belajar matematika siswa kelas 1 menggunakan model flipped classroom serta mengetahui respon mereka dalam penggunaan model tersebut. Subjek penelitian ini sebanyak 7 siswa yang merupakan siswa kelas 1 SD. Desain penelitian menggunakan penelitian tindakan kelas yang terdiri dari perencanaan, pelaksanaan, observasi dan refleksi. Data dianalisis secara diskriptif dengan pendekatan kualitative dan kuantitatif. Hasil penelitian menunjukkan bahwa nilai rata-rata pra-siklus sebesar 59, dan mengalami peningkatan pada siklus I menjadi 77 lalu menjadi 90 pada siklus II. Kriteria minimal adalah $>70$ sehingga siklus dihentikan pada siklus ke-II. Respon siswa dalam penggunaan model ini secara umum dapat dikatakan positif. Dimana sebagian besar menyatakan bahwa penerapan model ini memberikan kemudahan dalam mempelajari materi matematika, meningkatkan rasa percaya diri, fleksibilitas belajar, tanggung jawab, aktif dan bebas memilih gaya belajar. Walaupun model ini tidak ditemukan dapat meningkatkan kemandirian belajar secara optimal namun tetap dapat digunakan guna mengakomodasi kegiatan belajar mandiri di rumah dan
\end{abstract} melatih kemandirian belajar siswa kelas rendah.

\begin{abstract}
A B S T R A C T
The educational paradigm in the 21st-century coronavirus pandemic requires a deeper research study. This study aims to improve the mathematics learning outcomes of grade 1 students using the flipped classroom model and to find out their responses to the use of this model. The subjects of this study were 7 students who were grade 1 student. The research design used classroom action research consisting of planning, implementing, observing, and reflecting. Data were analyzed descriptively with qualitative and quantitative approaches. The results showed that the pre-cycle average value was 59, and an increase in cycle I became 77 and then 90 in cycle II. The minimum criteria are $>70$ so that the cycle is stopped in the second cycle. Student responses in using this model, in general, can be said to be positive. Where most stated that the application of this model made it easier to learn mathematical material, increased self-confidence, learning flexibility, responsibility, active and free to choose learning styles. Although this model was not found to increase learning independence optimally, it can still be used to accommodate independent learning activities at home and train the learning independence of low-grade student.
\end{abstract}

\section{Introduction}

Today technology is an inseparable part of the implementation of education. The 21st century brings various technological novelties to education (Cheng \& Mok, 2008) and becomes a digital era where teaching and learning are no longer limited to traditional classrooms. The application of 21st-century skills requires an environment with two elements in which we must increasingly put technology in the hands of students and must trust them with more progressive use of technology (Blair, 2012). Effective use of technology can be done by adding value to the traditional curriculum and teaching students who fail to respond to this traditional-approach (Shields \& Behrman, 2000). The traditional teaching approach where students are not active and teachers control everything is found insufficient by educators, especially with rapid technological developments (Yildirim \& Kiray, 2016). Often the learning is dominated by the teacher as a speaker who seems to stand on a stage. This existence makes students passive and makes it difficult for teachers to identify student abilities. To ensure students are not left behind, the teachers must go around and help students individually (Enfield, 2013). Also, active learning activities should be providing more opportunities for students to interact and learn from each other (Mok,

Copyright (C) Universitas Pendidikan Ganesha. All rights reserved. 
2014). In line with this, the traditional system that also requires students to multitask as listening, processing new information, and writing down points for future reference has stated is not the best way to convey new learning material (Drake et al., 2016). According to this, learning activities in the classroom ideally require more interaction between learners and teachers, also are oriented towards active learners and traditional teaching that makes learning ineffective should begin to be left.

The digital native generation or children who are raised by the rapid development of technology show a difference compared to the previous generations where there is a decrease in tolerance to the lecture style (Prensky, 2001). It is interesting to note that one of the impacts and reasons for the uses of Information and Communication Technology (ICT) that most frequently reported in primary schools is the increase in student motivation and engagement (Balanskat, 2007). Furthermore, there are case studies on improving learning relationships inside and outside of school, also parental involvement in the use of ICT (Balanskat, 2007). Even though technology comes with attractive offers, teachers still play a significant role. Computer as a tool and technology will not replace teachers but will provide educators a dynamic and relevant tool for improving the quality of education (Mazur, 1991). Therefore, it is necessary to use innovative mobile technology to make education available to anyone, anywhere, anytime, and at affordable costs worldwide (Keengwe \& Bhargava, 2013; Tahir \& Arif, 2016). In line with this, the use of educational applications for mathematics and vocabulary is considering by teachers to be more useful for elementary school students than content or other disciplines (Tahir \& Arif, 2016).

The Covid-19 pandemic that occurred in Indonesia opened a new chapter on education, where it is necessary to pay attention to the concept of distance learning or learn from home, technology-based, and blended learning. Teachers have to integrate the advantages of using technology that has been felt so far, with the demands of face-to-face learning towards a new normal. One of the learning models that can be used is the flipped classroom. This model can be an answer to the problems of traditional-learning that have always been complained about. One of the essential goals of a flipped classroom is to move away from dependence on teachers as information sources and class compilers. Thus, the lack of a student to pay attention, increase interest, and make connections with past experiences of a discipline due to a learning environment that is always teacher-centered can be left (Lumpkin \& M, 2015; Roehl et al., 2013).

A flipped classroom can be known as learning that is different from learning in general. The concept of flipped classrooms is what was traditionally done in the classroom is now done at home, and what was traditionally done as homework is now done in class (Bergman \& Sams, 2012; Ahmed, 2016) or in other words, direct learning from the big learning group becomes an individually study space with the help of one or more technologies (Hamdan et al., 2013; Zhou \& Jiang, 2014). Flipped classrooms change traditional learning from I do, we do, you do become You do, we do, I do. Homework, inquiry, and investigation implemented at school, while at home, students learn with the available content and bring the learning results the next day to school. Flipped classrooms have been used from elementary school to undergraduate programs (Schmidt, 2016). The implementation of flipped classrooms to students generally shows a positive response (Bishop \& Verleger, 2013). Students like this approach because if they do not understand the content, they can ask and discuss it in class (Fulton, 2012). Besides, students can save time listening to explanations in class because they have accessed learning through videos at home. Classroom activities may be used for discussion and solve problems (Halili \& Zainuddin, 2015). This model helps students to independent learning even when there is no teacher and in a formal classroom. Students also feel more confident in their abilities (Enfield, 2013) and are responsible for their own learning experiences (Bhakti et al., 2019) Students taught with this model has better self-efficacy than students who take conventional teaching (Zamnah, 2019).

A study reports that the implementation of flipped classrooms using video screencast technology had a significant impact on academic achievement (Flumerfert \& Green, 2012) or increased conceptual understanding (Saputra \& Mujib, 2018) compared to students who taught using traditional teaching, especially when adding quizzes (Alten et al., 2019). With that in mind, Clyde and Nancy also show that the implementation of flip classrooms has a positive impact on student learning (Herreid \& Schiller, 2013). The learning that implementing flipped classrooms involves the internet and instructional videos made by teachers. The video will be seen outside of learning by the students so that teachers can devote more time to interacting and communicating with students rather than teaching (Ahmed, 2016). The video as homework for students to study to prepare themselves for tomorrow's learning in class (Roehl et al., 2013). The videos disseminate by a website that is familiar to teachers and students and can be accessed easily by mobile devices. Video services such as YouTube and Vimeo are good choices in accessing and sharing videos (Moore et al., 2014). The use of video in the flipped classroom provides an opportunity for students to have a longer time to understand the material and play it repeatedly when they forget (Ario \& Asra, 2018). 
Education is for everyone, but how the teacher delivers learning and how students accept that is not the same as one each other. Flipped classrooms give teachers the flexibility to meet their students learning needs, while students get the flexibility to meet their needs in various ways (Sams \& Bergman, 2013). The various learning-styles of children so far have been neglected when the teachers adapt traditional learning. The pedagogical approach of the flipped classroom provides learners various learning styles. Besides, the use of this model can contribute to the educational environment. Students are encouraged to learn outside the classroom independently, in terms of place, time, and choosing the strategies they want (Uzunboylu \& Karagozlu, 2015). The learning for early-grade students cannot be supposed to be independent. The presence of teachers in classroom learning is necessary. However, traditional-learning that has been considered reasonable has shown various weaknesses when distance learning has to be implemented. Distance learning puts pressure on parents when they have to take responsibility for their children's study at home. Parents find it complicated to teach the children, especially when choosing the level and how to deliver the materials. According to these problems, it required a learning model to foster children's learning independence. Or in other words, teachers are no longer relied on as the only source of learning, and students can actively learn from anywhere and from anyone. Parents also are facilitated because they have parameters in helping children learn at home. In line with this, a flipped classroom model that promotes independent learning can be used as a solution to overcome this problem. Also, the flipped classrooms are reported to have been successful in building a good culture of interaction between learners, teachers, teaching materials, and technology media (Ishak et al., 2019). So that teachers, students, and parents are all active in children's learning activities. By considering the demands of a distance learning system towards face-to-face and considering the advantages of the model as an answer to the traditional teaching problems of the 21st Century technology, blended learning-based learning with the flipped classroom model is feasible to be used. This study aims to determine the effectiveness of the implementation of flipped classrooms and how students' perceptions of using this model.

\section{Method}

This research is a classroom action research that adapts the research model by Kemmis and Mc Taggart. This research consists of several steps, including planning, implementation, observation, and reflection (Kemmis et al., 2014; Kemmis \& McTaggart, 2000). The classroom action research was carried out in 2 cycles that were conducted from 27 November 2020 to 30 November 2020. This research subjects were grade 1 students of Ngadri 02 Binangun Blitar Elementary School with seven students. The selection of this research subject by the learning system that the school followed, which had carried out the mandate of the local government to carry out face-to-face meetings interspersed with online learning during the Covid-19 pandemic. Data collection techniques used were observation, tests, and questionnaires. The data collected consisted of pre-action scores, evaluation results at the end of the cycle, observations results, and student perceptions as users of the learning model. In this study, the instruments used to collect data were tests and surveys. The test is intended for the learning outcomes, while a questionnaire is intended for students' perceptions and levels of satisfaction with the application of the model. The test to be given is a mathematics subject test with integer arithmetic operations. The collected data will be analyzed using a descriptive approach where conclusions are drawn based on the whole data obtained. The success and completeness of the minimum students' learning outcomes are $>70$. While, the specific criteria for the acquisition of scores refer to the range of values 80-100 (Excellent), 6679 (Very Good), 56-65 (Good), 40-55 (Fair), and 30- 39 (Poor) (Arikunto, 2018). The survey consists of 25 questions in the form of definite and open-ended answer questions, which are the last questions on each sub-topic. Google Form platform used for conducting the survey. The question indicator refers to the (Enfield, 2013) research, which was later developed by the researcher. The sub-topic used as a reference for survey questions are as follows the instructional video made by the teacher of 5 questions, learning activities using learning videos of 15 questions, and learning activities in the classroom consist of 5 questions consisting of a Linkert and open-ended scale.

\section{Result and Discussion}

\section{Results}

Learning is carried out in 2 cycles with mathematical operations material. Cycle 1 contained the addition operation, while cycle 2 contained the subtraction operation. The implementation of this cycle adapts to learning flipped classroom where the teacher has provided learning videos for students to learn and as a companion to learning activities at home, followed by discussion activities the next day. The 
video' content made contained learning to count the number of objects, performing the addition or subtraction count operation on two types of things, and doing quizzes.

\section{Cycle I}

The implementation of cycle 1 begins by giving the video to students as a companion to learning activities. For the next day, it was continued with class activities such as discussion about the video content and the difficulties experienced by students, especially when working on quizzes and practicing counting operations using concrete objects. Teaching and learning activities showed that the result of the flipped classroom implementation obtained unsatisfactory results. From the seven students who participated in learning using the flipped learning model, three students got results below the minimum completeness value. So that learning in cycle 1 is still not getting optimal results.

Table 1. Evaluation Score of Cycle I Learning

\begin{tabular}{ccc}
\hline Subject & Score & Category \\
\hline 1 & 60 & Failed \\
2 & 100 & Passed \\
3 & 80 & Passed \\
4 & 80 & Passed \\
5 & 60 & Failed \\
6 & 100 & Passed \\
7 & 60 & Failed \\
\hline
\end{tabular}

Based on the learning observation activities carried out in cycle 1, it's known that students became more enthusiastic than in the previous meeting. It can be seen from the increasing number of students who actively ask the teacher. Some students also need direct guidance, so the teacher needs to come to them one by one. Early grade students show pleasure when the teacher comes and pays attention to them one by one. Even though students show their interest in learning activities, they still do not get optimal learning results.

\section{Cycle II}

Learning activities in cycle 2 using the flipped classroom model showed a satisfactory score. There is a significant difference compared to cycle 1 . Of the seven students who took part in the learning, all of them got a score above the minimum completeness value. Even though three of them still can't reach the maximum score.

Table 2. Evaluation Score of Cycle II Learning

\begin{tabular}{ccc}
\hline Subject & Score & Category \\
\hline 1 & 80 & Passed \\
2 & 90 & Passed \\
3 & 100 & Passed \\
4 & 100 & Passed \\
5 & 80 & Passed \\
6 & 100 & Passed \\
7 & 80 & Passed \\
\hline
\end{tabular}

The application of flipped classrooms in cycle 2 shows that students are quicker to grasp the teacher's explanation of the difficulties and questions they bring from home. It also applies when teachers and students experiment by performing numerical count operations using concrete objects around them. All students are actively involved in carrying out these activities.

Table 3. The Average Score on Learning

\begin{tabular}{llll}
\hline & Pre-Cycle & Cycle I & Cycle II \\
\hline Score & 59 & 77 & 90 \\
\hline
\end{tabular}




\section{Instructional video}

Students' perceptions of videos made by teachers and given to them, were explored through a survey consisting of questions 1-4. The first three questions contained attractiveness and video design, while the fourth question is an open question for students who have answers outside the choices provided.

Table 4. Responses to Survey Questions of Instructional Video.

\begin{tabular}{lllc}
\hline No. & \multicolumn{1}{c}{ Survey Questions } & \multicolumn{1}{c}{ Response } & \% \\
\hline 1 & Is The Video Given by The Teacher Helpful in Learning & Very helpful & $42,8 \%(3)$ \\
& Numerical Arithmetic Operations? & Somewhat helpful & $57,1 \%(4)$ \\
& & Not helpful & $0 \%(0)$ \\
2 & How Is The Material in The Video? & Very interesting & $71,4 \%(5)$ \\
& & Somewhat interesting & $28,5 \%(2)$ \\
& & Not interesting & $0 \%(0)$ \\
& How Is The Material In The Video? & Too difficult & $14,2 \%(1)$ \\
& & Appropriately & $71,4 \%(5)$ \\
4 & What About The 11 Minute Video Duration? & challenging & $14,2 \%(1)$ \\
& & Too easy & $28,5 \%(2)$ \\
& & Too long & $71,4 \%(5)$ \\
\end{tabular}

Most of the students showed a positive response to the video made by the teacher. None of the students provided additional notes and answers to open-ended questions.

\section{Learning experiences using content}

Student responses regarding learning experiences using videos provided by the teacher are presenting by a survey consisting of questions 5-20. Fourteen questions contained multiple choices related to the ease and fluency in accessing videos and the impact of individual learning activities after watching the video. Meanwhile, the fifteenth question is an open question. Students watched the video while taking notes to helped them understand the content better (85.7\%). Also, all students working on the quizzes provided in the video to help strengthen their understanding of the content (100\%). On the other side, students were found to experience technical problems such as streaming, downloading, pause, or playback (42.8\%). Some of them considered the disorder very disturbing (14.2\%), and the others did not mind the condition (28.5\%). The use of video in learning before face-to-face shows that students like these activities because they like learning from the videos (42.8\%), and the others like learning videos because these activities are tasks and responsibilities that need to be fulfilled. However, based on the survey was found that one student disliked learning to use video (14.2).

The use of video makes all students feel responsible for their learning activities because it will be discussed in future meetings (100\%). Furthermore, a student claimed that watching the video was not his learning style, while the other claimed that watching the video made them more flexible to adjust their learning styles (28.5\%). In line with this, a student claimed that watching the video did not have a significant impact on class activities (28.5\%). Meanwhile, the rest (71.4\%) claimed that listening to videos on the previous day made them more active in-class learning activities because they understood the topics discussed on that day much more and went to school with notes they needed to discuss and asked the teacher.

Table 4. Responses to Survey Questions of Learning Experiences

\begin{tabular}{llll}
\hline No. & \multicolumn{1}{c}{ Survey Questions } & \multicolumn{1}{c}{ Response } & $\%$ \\
\hline 1 & How Does Using Video & I like learning by watching videos & $42,8 \%(3)$ \\
& Impact Learning Motivation? & I like learning by watching videos because the \\
& & material in the videos will be reviewed in the \\
& & next meeting & $42,8 \%(3)$ \\
& & I don't like learning by watching videos & $14,2 \%(1)$ \\
2 & Learning with Videos Made & More independent & $0 \%(0)$ \\
& Me: & Can learn independently, but sometimes & $100 \%(7)$
\end{tabular}




\begin{tabular}{llll}
\hline No. & \multicolumn{1}{c}{ Survey Questions } & \multicolumn{1}{c}{ Response } & \multicolumn{1}{c}{$\%$} \\
\hline \multirow{3}{*}{3} & Learning from The Video & Less independent and depend on parents & $0 \%(0)$ \\
About Content to be & Confident that I will be able to take part in & $71,4 \%(5)$ \\
Discussed Tomorrow Made & tomorrow's lessons. & I prepare as best I can, but still worried. & $28,5 \%(2)$ \\
Me: & $\begin{array}{l}\text { Nothing changes, I do not intend to prepare for } \\
\text { tomorrow. }\end{array}$ & $0 \%(0)$ \\
4 & Learning with Videos Made & More flexible in study time & $85,7 \%(6)$ \\
& Me: & Does not affect daily study time & $14,2 \%(1)$ \\
& Less flexible and burdens me because I have to & $0 \%(0)$ \\
& study &
\end{tabular}

\section{Acivities in the classroom}

Students' responses to activities in the classroom are explored through questions 20-25. This section consists of 5 questions regarding the types of learning activities that are of most interest to students. 4 questions are packaged using a Linkert scale, while the last question is an open question.

Table 12. Response to Learning Activities in Class

\begin{tabular}{ll}
\hline Activity & Score \\
\hline Learn new content through teacher explanations in class. & 31 \\
Learn new content at home using video and will be discussed in the class & 33 \\
tomorrow. & 25 \\
Choose homework about tomorrow's learning content. & 28 \\
Choose homework about today's learning content. & \\
\hline
\end{tabular}

Students show a positive response regarding learning new material or content before the class meeting. However, students prefer homework (PR) like their general days because they can practice doing the quiz about what they have learned in school. Some students stated that homework to watching the video about the content to be discussed is expected to provide many practice questions.

\section{Discussion}

The flipped classroom is a way to change the traditional learning system by involving a technological approach. This research found various advantages and positive responses in implementing flipped classrooms. According to previous research, flipped classroom implementation provides a significant increase in the quality of student learning. Although, flipped classrooms are not prepared to improve learning outcomes. However, from the average score obtained before and after the treatment, it can be concluded if student engagement affected learning outcomes scores. Also, the improvement in academic achievement by the learning outcome scores, in which there was a significant increase in test scores after the implementation (Talan \& Gulsecen, 2019). The score may increase because of differences in the quality of teaching materials, classroom activities, teachers, or teaching methods.

Flipped classrooms have long been discovering to increase student independence. In line with that, flipped learning improves student learning independence (Papachristopoulus \& Lakin, 2016). But, it is not entirely in line with what has been found in this study. Even though students claimed that they could study independently, they still need guidance from their parents when learning at home. Likewise, when referring to the characteristics of early-grade students, this can be understood as something normal. Children at the beginning of schooling still carry habits from home and parental education (Bridgemohan, 2001). Children not independent, so education and parents must focus on developing children's learning independence. The application of flipped classrooms to early-grade students can be an opportunity to increase their independence in learning and gradually let go of their dependence on adults in their learning activities. Although children are supposed to be independent in learning activities, the interactions between children and parents should be noticed when applying the model. The involvement of parents in education has been shown an effect on student achievement, attitude, and aspirations (Epstein, 1987). In general, students who took this lesson stated that they had more confidence in their ability to participate in the future. In line with this, flipped classrooms increase the self-efficacy of elementary school students, it can be understood based on the learning concept promoted by the flipped classroom, where students can access interesting learning videos the day before face-to-face meetings (Sharma \& Chowdhry, 2018). They prefer the content and idea of what tomorrow will teach. 
Flipped classrooms affect time flexibility and student learning styles. Although, it was found that some students preferred the presence of their teacher when explaining rather than watching videos or other learning styles. Understandably, early-student those who at an early age or have just graduated from kindergarten have dependencies that include a sense of possessiveness and attachment to their teachers (Birch \& Ladd, 1997). In line with this, excessive dependence on teachers should be minimal over time. excessive dependence on teachers has negative implications where children lose opportunities for autonomous exploration of the classroom environment and peer involvement (Split et al., 2017). Consistent implementation of the flipped classroom can be a solution to this situation. Students will be more active as learners where they can access their learning material independently and optimize collaborative activities and classroom practice. So, students will continue to learn even without the teacher because their teacher is not the only learning source. In this research, the videos are made in such a way as to involve students actively. According to Dale, learning will be less permanent if the information is conveyed passively through verbal symbols, and it will be very permanent if learning activities involve students. The video in this study occupies a position in the middle of the dale's cone experience, where students are invited to be involved in learning activities by counting and doing joint exercises. Meanwhile, in terms of duration, the 11-minute video was judged by the majority of students to be correct. When viewed based on research that has been carried out by experts, the implementation of flipped classrooms will be successful if the video duration is relatively short, which is no more than 20 minutes (Houston \& Lin, 2012).

\section{Conclusion}

The implementation of the flipped classroom in early grade students constrained by the large dependency and desire to study with their teachers in class. Even though early grade children do not tend to choose flipped classrooms or traditional learning, in other words, they can still follow both. However, the flipped classrooms have succeeded in solving traditional-classroom problems and answering the challenges of learning technology in the 21st century. Also, this model has a positive effect on improving the academic achievement of mathematics and was responded to positively by most students, especially about their study habits. Thus, this model should be considered in current learning, especially in the transition to the new normal after the pandemic. Also, this learning model can be a stimulus for early students to become more independent and active. The deeper factors of each student's response, especially those related to how the teacher teaching in the class, should be explored in the future.

\section{References}

Ahmed, H. O. K. (2016). Flipped Learning as A New Educational Paradigm: An Analitical Critical Study. European Scientifiec Journal, 12(10), 417-444. https://doi.org/10.19044/esj.2016.v12n10p417.

Alten, D. C. . van, Phielix, C., Janssen, J., \& Kester, L. (2019). Effect of flipping the classroom on learning outcomes and satisfaction: a meta-analysis. Educational Research Review, 28(100281), 1-18. https://doi.org/10.1016/j.edurev.2019.05.003.

Arikunto, S. (2018). Dasar-Dasar Evaluasi Pendidikan. Bumi Aksara.

Ario, M., \& Asra, A. (2018). Pengaruh Pembelajaran Flipped Classroom Terhadap Hasil Belajar Kalkulus Integral Mahasiswa Pedidikan Matematika. Jurnal Ilmiah Pendidikan Matematika, 1(2), 82-88.

Balanskat, A. (2007). Study of the impact of technology in primary schools.

Bergman, J., \& Sams, A. (2012). Flip Your Classroom: Reach Every Student in Every Class Every Day. International Society for Technology in Education.

Bhakti, Y. B., Astuti, I. A. D., Sumarni, R. A., Sulisworo, D., \& Toifur, M. (2019). Flipped Classroom as a Millenial Teaching Model. Indonesian Review of Physics, 2(1), 22-27.

Birch, S. H., \& Ladd, G. W. (1997). The teacher-child relationship and children's early school adjustment. Journal of School Psychology, 35(1), 61-79. https://doi.org/Birch, S. H., \& Ladd, G. W. (1997). The teacher-child relationship and children's early school adjustment. Journal of School Psychology, 35(1), 61-79. doi:10.1016/s0022-4405(96)00029-5.

Bishop, J. L., \& Verleger, M. A. (2013). The Flipped Classroom: A Survey of the Research. 120th ASEE Annual Conference \& Exposition, 1-18.

Blair, N. (2012). Technology Integration for the "New" 21st Century Learner. Principal, 91(3), 8-13.

Bridgemohan, R. R. (2001). Parent Involvement In Early Childhood Development In Kwazulu Natal. University Of South Africa.

Cheng, Y. C., \& Mok, M. M. . (2008). What effective classroom? Toward a paradigm shift. School Effectiveness and School Improvement: An International Journal of Reasearch, Policy and Practice, 
19(4), 365-385. https://doi.org/http://dx.doi.org/10.1080/09243450802535174.

Drake, L., Kayser, M., \& Jacobwitz, R. (2016). The Flipped Classroom: An Approach to Teaching and Learning. A 2020 Vision For Public Education in Ulster County, 1-15.

Enfield, J. (2013). Looking at the impact of the flipped classroom model of instruction on undergraduate multimedia student at CSUN. TechTrends, 57(6), 14-27. https://doi.org/10.1007/s11528-0130698-1.

Epstein, J. (1987). Parent Involement: What research says to administration. Education and Urban Society, 19(2), 119-136.

Flumerfert, S., \& Green, G. (2012). Using lean in the flipped classroom for at risk students. Educational Technology \& Society, 16(1), 356-366.

Fulton, K. (2012). Upside down and inside out: Flip your classroom to improve student learning. Learning \& Leading with Technology, 39(8), 12-17.

Halili, S. H., \& Zainuddin, Z. (2015). Flipping The Classroom: What We Know and What We Don't. Journal of Distance Education and E-Learning, 3(1), 15-22.

Hamdan, N., McKnight, P., McKnight, K., \& Arfstrom, K. M. (2013). A Review of Flipped Learning. Pearson.

Herreid, C. F., \& Schiller, N. A. (2013). Case Studies and the Flipped Classroom. Journal of College Science Teaching, 45(5), 62-66.

Houston, M., \& Lin, L. (2012). Humanizing the Classroom by Flipping the Homework versus Lecture Equation. Society for Information Technology \& Teacher Education International Conference, 11771182.

Ishak, T., Kurniawan, R., \& Zainuddin, Z. (2019). Implementasi model pembelajaran flipped classroom guna meningkatkan interaksi belajar mahasiswa pada mata kuliah manajemen informasi dan EAdministrasi. Jurnal Kajian Teknologi Pendidikan, 4(2), 89-95.

Keengwe, J., \& Bhargava, M. (2013). Mobile learning and integration of mobile technologies in education. Education and Information Technologies, 19(4), 737-746. https://doi.org/10.1007/s10639-0139250-3.

Kemmis, S., \& McTaggart, R. (2000). Participatory Action Research Planner (2nd ed.). Sage.

Kemmis, S., McTaggart, R., \& Rhonda, N. (2014). The Action Research Planner. Springer. https://doi.org/DOI 10.1007/978-981-4560-67-2.

Lumpkin, A., \& M, A. R. (2015). Flipping a Class: Active Learning and More of it. Sport Management Educational Journal, 9(2), 79-90. https://doi.org/10.1123/SMEJ.2014-0042.

Mazur, E. (1991). Can we teach computers to teach? Computers in Physics, 5(31), 33-38. https://doi.org/https://doi.org/10.1063/1.4822968.

Mok, H. N. (2014). Teaching tip: The flipped classroom. Journal of Information System Education, 25(1), 711.

Moore, A. J., Gillet, M. R., \& Steele, M. D. (2014). Fostering Student Engagement with The Flip. The Mathematics Teacher, 107(6), 420-425.

Papachristopoulus, G., \& Lakin, E. (2016). Flipped Classroom and Independent Learning. Hellenic Conference on Innovating STEM Education, 1-9.

Prensky, M. (2001). Digital Natives, Digital Immigrants. On the Horizon, 9(5), 1-6.

Roehl, A., Reddy, S. L., \& Shannon, G. J. (2013). The Flipped Classroom: An Opportunity To Engage Millenial Students Through Active Learning Strategies. Journal of Family and Consumer Sciences, 105(2), 44-49.

Sams, A., \& Bergman, J. (2013). Flip Your Students Learning. Educational Leadership, 70(6), 16-20.

Saputra, M. E. A., \& Mujib. (2018). Efektivitas Model Flipped Classroom Menggunakan Video Pembelajaran Matematika terhadap Pemahaman Konsep. Desimal: Jurnal Matematika, 1(2), 173-179.

Schmidt, S. M. . (2016). The Flipped Classroom: A Twist on Teaching. Contemporary Issues in Educational Research, 9(1), 1-6.

Sharma, H. L., \& Chowdhry, M. (2018). Improving the work ability confidence of elementary school students using flipped classroom strategy: focused on the class activities with problem posing and solving. International Journal of Research and Analytical Reviews, 5(4), 257-268. https://doi.org/10.13140/RG.2.2.35841.30561/1.

Shields, M. K., \& Behrman, R. E. (2000). Children and Computer Technology: Analysis and Recommendation. The Future of Children, 10(2), 4-33. https://doi.org/10.2307/1602687.

Split, J. L., Vervoort, E., \& Verschueren, K. (2017). Teacher-Child Dependency and Teacher Sensitivity Predict Engagement of Children with Attachment Problems. School Psychology Quarterly, 33(3), 419-427. https://doi.org/10.1037/spq0000215.

Tahir, R., \& Arif, F. (2016). Technology in Primary Schools: Teachers Perspective towards the Use of Mobile Technology in Children Education. In Emerging Trends and Advanced Technologies for 
Computational Intellegence (pp. 103-129). Springer, Cham. https://doi.org/10.1007/978-3-31933353-3_6.

Talan, T., \& Gulsecen, S. (2019). The Effect of a Flipped Classroom on Students' Achievements, Academic Engagement and Satisfaction Levels. Journal of Distance Education, 20(4), 31-60. https://doi.org/10.17718/tojde.640503.

Uzunboylu, H., \& Karagozlu, D. (2015). Flipped Classroom: A Review of Recent Literature. World Journal on Educational Technology, 7(2), 142-147. https://doi.org/http://dx.doi.org/10.18844/wjet.v7i2.46

Yildirim, F. S., \& Kiray, S. A. (2016). Flipped Classroom Model In Education. Research Highlights in Education and Science, 1-8.

Zamnah, L. N. (2019). Implementation of peer instruction flipped classroom to improve self-efficacy of underprivileged students. Jurnal Pendidikan Dan Pengajaran, 52(2), 69-74.

Zhou, G., \& Jiang, X. (2014). Theoritical Research and Instructional Design of the Flipped Classroom. Applied Mechanics and Materials, 543-547, 4312-4315. https://doi.org/doi:10.4028/www.scientific.net/amm.543-547.4312. 